the developing brain. A Ciba Foundation Symposium (Associated Scientific Publishers, Amsterdam, 1972).

6. Folch, J., Lees, M., and Scoane Stanley, G. H.: A simple method for the isolation and purification of total lipids from animal tissues. J. Biol. Chem., 226: 497 (1957).

7. Jurand, A.: The effect of hydrocortisone acetate on the development of mouse embryos. J. Embryol. Exp. Morphol., 20: 355 (1968).

8. Lovern, J. A.: The Chemistry of Lipids of Biologic Significance. (John Wiley and Sons., Inc., New York, 1955).

9. Lowry, O. H., Rosebrough, N. J., Farr, A. L., and Randall, R. J.: Protein measurements with the Folin phenol reagent. J. Biol. Chem., 193: 265 (1951).

10. Martinek, R. G.: Evaluation of a modification of the Zak-Kiliani reaction for determination of the serum cholesterol. Clin. Chem., 11(4): 495 (1965)

11. Moscona, M. H., and Karnosky, D. A.: Cortisone induced modifications in the development of the chick embryo. Endocrinology, 66: 533 (1960.

12. Oppenheimer, E.: Lesions in the adrenals of an infant following maternal corticosteroid therapy. Bull. Johns Hopkins Hosp., 114: 146 (1964).

13. Prensky, A. L., Mosis, A., Fishman, M., Tumblesen, M. E., and Daftari, B.: The lipid composition of the cerebral hemisphere of the miniature pig (sus scrofa), during development. Comp. Biochem. Physiol., 39: B 725 (1971)

14. Sames, G. L., and Leatham, J.: Influence of desoxycorticosterone and cortisone acetate on body weight of chick embryos. Proc. Soc. Exp. Biol. Med., 78: 231 (1951).

Copyright (1) 1977 International Pediatric Research Foundation, Inc.
15. Sato, H.: Effect of adrenocroticoids during pregnancy. Lancet, Vol. 11, 7319: 1235 (1963)

16. Shorr, E.: A new technique for staining vaginal smears: A single differential stain. Science, 94: 545 (1941)

17. Timiras, P. S., Vernadakis, A., and Sherwood, N.: In: N. S. Assali: Biology of Gestation, Vol. 2, p. 261 (Academic Press, New York, 1968).

18. Vernadakis, A., and Woodbury, D. M.: Electrolyte and aminoacid changes in rat brain during maturation. Amer. J. Physiol., 203: 748 (1962).

19. Yackel, D. B., Dempers, R. D., and McConahey, W. M.: Adrenocorticosteroid therapy in pregnancy. Amer. J. Obstet. Gynecol., 96: 985 (1966).

20. Zoliner, N., and Kirsch, K.: Uber die quantitative Bestimmung von lipoiden (Mikro-méthode) mittel der vielen naturlichen lipoiden (allen bekanten plasmalipoiden). Z. Ges. Exp. Med., 135: 545 (1962).

21. The authors are indebted to Dr. E. A. Pedernera for helpful discussion; to Mr. N. G. Amar for skillful technical assistance; to Miss M. Wagener for cooperation in some laboratory works, and to Dr. Roberto A. Prado-Alcalá for reviewing the manuscript. Statistical analysis was performed by Miss B. M. Pérez.

22. Reagents were kindly supplied by Wiener Laboratories.

23. Requests for reprints should be addressed to: M. C. Romano, M.D., Depart. de Fisiologia, Facultad de Medicine, Apdo. Postal 70250, Mexico 20, D. F. (U. N. A. M.)

24. Received for publication February 17, 1977

25. Accepted for publication March 2, 1977.

\title{
The Activity of Galactose-1-phosphate Uridyltransferase and Galactokinase in Human Fetal Organs
}

\author{
Y. S. SHIN-BUEHRING, T. BEIER, A. TAN, M. OSANG, AND J. SCHAUB' ${ }^{(35)}$ \\ Children's Hospital, University of Munich, Munich, West Germany
}

\section{Summary}

The activity of galactose-1-phosphate uridyltransferase (transferase) and galactokinase in several organs from human fetuses 7-28 weeks old was measured by using radioactive substrates and column chromatography for product identification. The specific activity of transferase and galactokinase increased with gestational age and reached, at the 28th week, a maximal level of 30.0 and $7.9 \mathrm{nmol} / \mathrm{min} / \mathrm{mg}$ protein (units) in liver, 4.7 and 2.5 units in kidney, 6.0 and 4.0 units in lung, 6.7 and 2.9 units in spleen, 5.2 and 2.6 units in cardiac muscle, and 4.0 and 1.4 units in skeletal muscle, respectively. The activity in brain, on the other hand, remained quite constant with 1.2 units in the case of transferase and 0.5 units in the case of galactokinase during this period. The activities of both enzymes in the liver of children were slightly lower than the highest fetal level during the period of pregnancy studied. Galactokinase activity in fetal erythrocytes was approximately 4 times higher and the transferase activity approximately $30 \%$ higher than in adults. The $K_{m}$ value of fetal liver transferase for galactose-1-phosphate was found to be $0.330-0.357 \mathrm{mM}$ and that of galactokinase for galactose, $0.265-0.277 \mathrm{mM}$.

\section{Speculation}

It is postulated that the regulation of fetal galactokinase and transferase in brain is different from that in other organs with respect to the inducibility and development of these enzymes since the specific activities remained constant during a 5-month period of pregnancy in brain, in contrast to other organs. In view of the observation that the liver of a galactosemic child contained an uridyltransferase with extremely low binding affinity for galactose-1-phosphate, one of the causes for classic galactosemia may be altered binding sites rather than the complete absence of this enzyme.

Galactokinase (EC. 2.7.1.6) deficiency is an inborn error of galactose metabolism accompanied with galactosemia and galactosuria, which are caused by the inability to phosphorylate galactose to galactose-1-phosphate $(8,9)$. Another disorder of galactose metabolism known as classic galactosemia is characterized by the virtual absence of the galactose-1-phosphate uridyltransferase (EC. 2.7.7.12) which catalyzes the reaction galactose-1phosphate + UDP-glucose = glucose-1-phosphate + UDP-galactose. These enzymes have been observed in human erythrocytes $(12,14,24)$, leukocytes $(5,20)$, and in human liver $(2$, 25 ), and the defect of the enzymes in some of these tissues or cultured fibroblasts was found in galactosemic and galactokinase-deficient patients. The prenatal diagnosis of these genetic maladies can be accomplished by measuring the enzyme activity in cultured amnion cells $(6,23)$. 
It was reported that galactose is metabolized in infants at a considerably higher rate than in adults $(5,26)$. Donnell and coworkers (5) found that galactokinase activity in human erythrocytes decreased during the first 3 years of life, reaching a level at 3-6 years of age comparable to that found for adults. The affinity of fetal erythrocytic galactokinase to galactose is lower than in adults, whereas the maximal velocity of the fetal enzyme is greater than that of the adult enzyme $(19,28)$. It was also suggested that at least two different kinds of galactokinase are present in rat liver: a fetal and an adult enzyme (4). According to Hammerson and coworkers (10), however, human galactokinase in either erythrocytes or cultured fibroblasts appears to have an identical electrophoretic mobility to adult enzymes in both tissues, respectively. For uridyltransferase, on the other hand, there is little difference in human erythrocytic activity between newborn and adult $(11,21)$. However, the transferase activity in newborn rat liver and intestine is almost 3 times higher than that in respective adult organs.

It is rather difficult at this point to make any conclusions with regard to the differences between fetal and the adult enzymes in various tissues and with regard to the significance of possible differences. Furthermore, the characteristics of fetal liver enzymes and the contribution of enzymes from other organs such as brain, kidney, muscle, heart, or lung to the overall galactose metabolism in human have not been well known until now. The present study deals with these problems by examining the developmental changes of fetal galactokinase and transferase from several human organs and by studying the characteristics of fetal liver enzymes.

\section{MATERIALS AND METHODS}

\section{MATERIALS}

Galactose-1-phosphate, UDP-glucose, galactose, hexokinase, and ATP were obtained from Boehringer, Mannheim, West Germany. $\left[{ }^{14} \mathrm{C}\right]$ Galactose $(60 \mathrm{mCi} / \mathrm{mmol})$ and ${ }^{14} \mathrm{C}$-galactose-1phosphate $(384 \mathrm{mCi} / \mathrm{mmol})$ were from Amersham Buchler, Braunschweig, West Germany; Triton X-100, PPO, POPOP, and toluene were from Carl Roth, Karlsruhe, West Germany; Cystine- $\mathrm{HCl}$ and $\mathrm{NaF}$ were from Merck, Darmstadt, West Germany.

\section{TISSUE SAMPLES}

All fetuses were legally aborted by the administration of prostaglandin and dissected immediately. The organs, liver, kidney, heart, muscle (M. quadriceps), lung, spleen, and brain tissues were removed from the fetuses and rinsed with saline. After they were dried with tissue papers, the tissues were homegenated in 5 volumes distilled water containing $10 \mathrm{mM} 2$-mercaptoethanol by a Potter Elvehjem homogenizer with a Teflon pestle for $5 \mathrm{~min}$. The preparation was then centrifuged at 10,000 $\mathrm{rpm}$ for $20 \mathrm{~min}$ at $4^{\circ}$, and the supernatant frozen until used. Galactokinase assay was done as soon as possible, usually within a week of storage, since the enzyme was found to be very unstable, i.e., $20-50 \%$ of the enzyme activity was lost within 2 weeks of storage at $-20^{\circ}$. Transferase was shown to be stable for at least 2 months at $-20^{\circ}$.

Three liver samples from healthy subjects, one infant and two children, as well as one sample from a galactosemic child, were obtained by puncture biopsy. The first three individuals were subjected to biopsy because of unexplained elevation of serum transaminase and hepatomegaly, and were later diagnosed as healthy.

\section{ENZYME ASSAY}

Transferase activity was determined by the carbon- 14 method of Bertoli and Segal (3) as modified later in our laboratory (27). The incubation mixture contained $0.25 \mathrm{M}$ glycine- $\mathrm{NaOH}, \mathrm{pH}$ $8.2,0.1 \mathrm{M}$ cysteine- $\mathrm{HCl}, \mathrm{pH} 8.2,1.1 \mathrm{mM}(0.1 \mu \mathrm{Ci} / \mathrm{ml})$ $\left[{ }^{14} \mathrm{C}\right.$ ]galactose-1-phosphate, and $0.4 \mathrm{mM}$ UDP-glucose. The reaction was initiated by the addition of $0.1 \mathrm{ml}$ of the above mixture to $50 \mu \mathrm{l}$ of the enzyme preparation containing 5-15 $\mathrm{gg}$ protein in the case of liver and 10-30 $\mu \mathrm{g}$ protein in the case of other organs. The method of Cuatrecasas and Segal (4), as modified further in this laboratory (28), was employed for galactokinase assay. The incubation mixture contained $0.25 \%$ saponin, $4 \mathrm{mM} \mathrm{NaF}, 8 \mathrm{mM} \mathrm{MgCl}, 0.4 \mathrm{mM}\left[{ }^{14} \mathrm{C}\right.$ ]galactose $(0.1$ $\mu \mathrm{Ci} / \mathrm{ml}), 200 \mathrm{mM}$ Tris- $\mathrm{HCl}, \mathrm{pH} 8.0,7.5 \mathrm{mM}$ ATP, and $10 \mathrm{mM}$ 2 -mercaptocthanol. To $100 \mu \mathrm{l}$ of the above solution, $50 \mu \mathrm{l}$ of the enzyme preparation containing $10-50 \mu \mathrm{g}$ protein in the case of liver, and 50-100 $\mu \mathrm{g}$ protein in the case of other organs were added for the initiation of the incubation. After $1 \mathrm{hr}$ of incubation at $37^{\circ}$, the reaction was stopped by heating at $95^{\circ}$ for 3 $\min$. The contents were then cooled, centrifuged, and $100 \mu \mathrm{l}$ of the supernatant chromatographed on DEAE-cellulose column to separate the products from the substrates $(27,28)$. The formation of products was linear with incubation time up to $1 \mathrm{hr}$ in the case of both enzymes, and with protein concentration of liver preparations up to $15 \mu \mathrm{g}$ for uridyltransferase and $75 \mu \mathrm{g}$ for galactokinase. (Fig. 1, $a$ and $b$ ). Protein was measured by the method of Lowry et al. (18) further adapted in our laboratory. The enzyme activities are expressed as nanomoles of product produced per min per $\mathrm{mg}$ protein. The assay procedures for erythrocytic enzymes were described in previous publications $(27,28)$.

\section{IDENTIFICATION OF PRODUCT}

A 2-ml disposable plastic syringe, the bottom of which was filled with glass wool, was packed with slurry of DEAE-cellulose ( $\mathrm{Cl}$ form for uridyltransferase and $\mathrm{OH}$ form for galactokinase) up to the $0.8 \mathrm{ml}$ marker. After $100 \mu \mathrm{l}$ of the supernatant were loaded onto the column, three $2-\mathrm{ml}$ fractions were eluted with distilled water in the case of galactokinase and with $20 \mathrm{mM} \mathrm{HCl}$
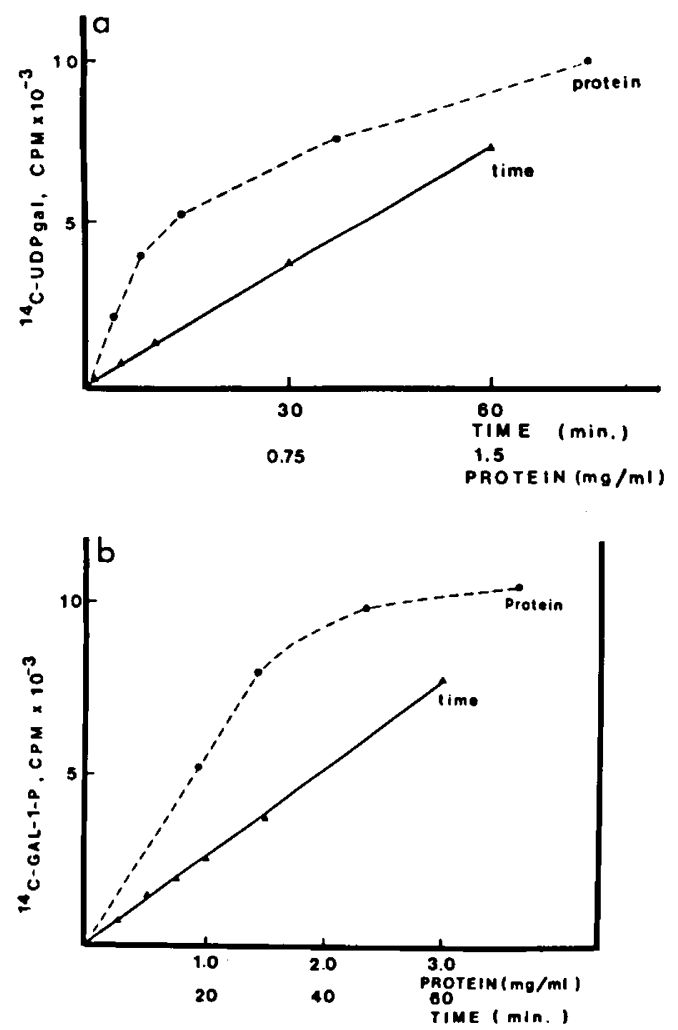

Fig. 1. Effect of time and protein concentration on enzyme velocities in fetal livers. ${ }^{14} \mathrm{C}-$ UDP $_{\text {Ral }}:\left[{ }^{14} \mathrm{C}\right]$ UDP-galactose; ${ }^{14} \mathrm{C}-\mathrm{GAL}-1-\mathrm{P}:\left[{ }^{14} \mathrm{C}\right]$ galactose-1-phosphate. $a$ : uridyltransferase, $b$ : galactokinase. 
in the case of uridyltransferase, and two 2-ml fractions were loaded with $100 \mathrm{mM} \mathrm{HCl}$. All of the fractions were collected directly into the plastic scintillation vials. The radioactivity was then determined in $10 \mathrm{ml}$ scintillation fluid consisting of $3 \mathrm{~g}$ PPO, $0.2 \mathrm{~g}$ POPOP, and $350 \mathrm{~g}$ Triton $\mathrm{X}-100$ in $750 \mathrm{ml}$ toluene. The blank was prepared from samples in which the protein was denatured by heating before the initiation of the incubation.

\section{PURIFICATION OF $\left[{ }^{14} \mathrm{C}\right] \mathrm{GALACTOSE}$}

$\left[{ }^{14} \mathrm{C}\right] \mathrm{Galactose}$ was treated with hexokinase to remove traces of other hexoses, mainly glucose. The reaction mixture contained $50 \mu \mathrm{Ci}^{4} \mathrm{C}$-galactose, $1 \mathrm{mM} \mathrm{MgCl} 2,1 \mathrm{mM} \mathrm{ATP}, 5 \mathrm{mM}$ Tris- $\mathrm{HCl}, \mathrm{pH} 8.0$, and $1 \mathrm{IU}$ of hexokinase to a final volume of 1 $\mathrm{ml}$. After the reaction mixture was incubated for $60 \mathrm{~min}$ at $37^{\circ}$, it was stopped by heating and was chromatographed on a DEAEcellulose column $(0.9 \times 2.0 \mathrm{~cm})$. The column was first eluted with $5 \mathrm{ml}$ distilled water and then with $100 \mathrm{mM} \mathrm{HCl}$. Water eluates contained $\left[{ }^{14} \mathrm{C}\right]$ galactose. The $100 \mathrm{mM} \mathrm{HCl}$ eluate contained $\left[{ }^{14} \mathrm{C} \mid\right.$ glucose-6-phosphate. We found consistently $2-5 \%$ of total radioactivity in the $100 \mathrm{mM}$ elute, depending on the radioactive batches.

\section{RESULTS}

\section{KINETIC DATA}

Maximal transferase activity in fetal livers was found to be at pH 8.2 (Fig. $2 a$ ), and maximal galactokinase activity at $\mathrm{pH} 7.9$ (Fig. $2 b) . \mathrm{K}_{\mathrm{m}}$ values were calculated from Lineweaver-Burk plots (17).

$K_{m}$ values of the transferase for galactose-1-phosphate in liver were obtained by using galactose-1-phosphate concentrations of $5.0,2.5,1.25,0.6,0.3,0.16,0.08,0.04$, and $0.02 \mathrm{mM}$ at a constant UDP-glucose concentration of $0.267 \mathrm{mM} . \mathrm{K}_{\mathrm{m}}$ values for galactose-1-phosphate of fetal liver enzyme were between
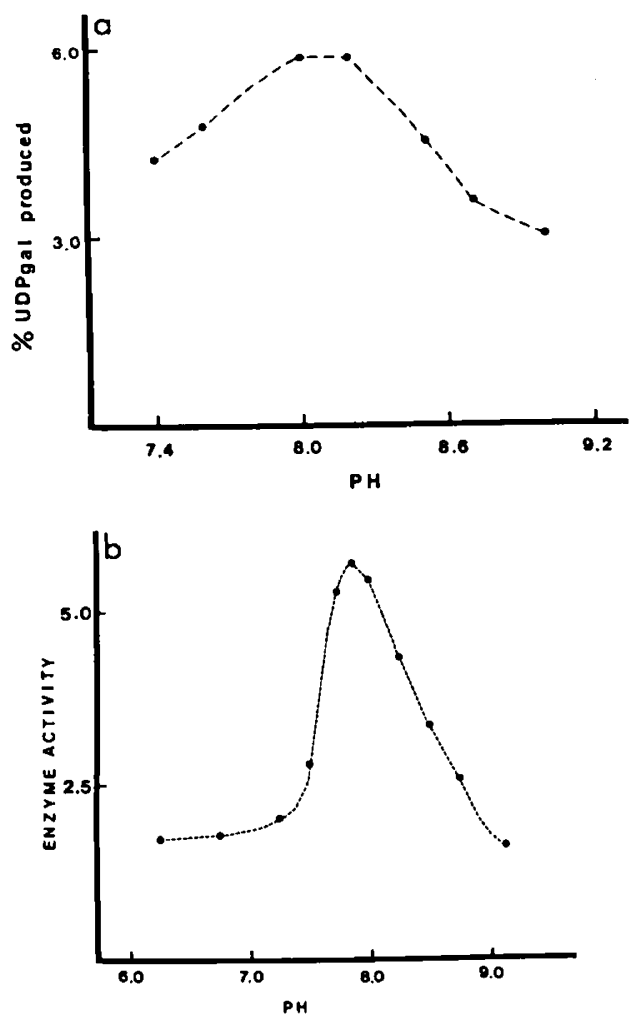

Fig. 2. $\mathrm{pH}$ dependence of fetal uridyltransferase $(a)$ and galactokinase (b). UDP gal $_{\text {: UDP-galactose. }}$
Table 1. $K_{m}$ values of liver galactokinase and uridyltransferase for galactose, galactose-1-phosphate (Gal-1-P), and UDP-glucose

\begin{tabular}{|c|c|c|c|c|}
\hline \multirow[b]{2}{*}{$\begin{array}{c}\text { Sample } \\
\text { no. }\end{array}$} & \multirow[b]{2}{*}{$\mathrm{Age}^{1}$} & \multirow{2}{*}{$\begin{array}{c}\mathrm{K}_{\mathrm{m}} \text { galactoki- } \\
\text { nase for } \\
\text { galactose, } \\
\mathrm{mM}\end{array}$} & \multicolumn{2}{|c|}{$\mathrm{K}_{\mathrm{m}}$ uridyltransferase } \\
\hline & & & $\begin{array}{c}\text { Gal-1-P, } \\
\mathrm{mM}\end{array}$ & $\begin{array}{l}\text { UDP-glu- } \\
\text { cose, } \mathrm{mM}\end{array}$ \\
\hline Fetus $I$ & 7 weeks & & 0.356 & \\
\hline Fetus 2 & 14 weeks & 0.227 & & 0.140 \\
\hline Fetus 3 & 20 weeks & 0.267 & 0.357 & \\
\hline Fetus 4 & 23 weeks & 0.270 & & \\
\hline Fetus 5 & 27 weeks & 0.270 & & \\
\hline Fetus 6 & 40 weeks & & 0.330 & 0.167 \\
\hline Infant 1 & 1.5 years & & 0.309 & \\
\hline Child 1 & 4.5 years & & 0.340 & \\
\hline
\end{tabular}

${ }^{1}$ For fetuses, this indicates gestational age.

0.330 and $0.357 \mathrm{mM} . \mathrm{K}_{\mathrm{m}}$ values for UDP-glucose at a constant galactose-1-phosphate concentration of $0.73 \mathrm{mM}$ were approximately 0.14-0.167 $\mathrm{mM}$ (Table 1). As shown in Table 1, the Michaelis constants of liver transferase from the fetuses, the infant, and the child are quite similar.

$\mathrm{K}_{\mathrm{m}}$ values of fetal liver galactokinase for galactose were found to be $0.265-0.277 \mathrm{mM}$ when measured by using galactose concentrations of $6.4,3.2,1.6,0.8,0.4,0.2,0.1$, and $0.05 \mathrm{mM}$ at a constant ATP concentration of $5.0 \mathrm{mM}$ (Table 1 ).

\section{ENZYME DEVELOPMENT}

Figure 3,a-g, represents developmental changes in specific activities of transferase in liver, kidney, brain, spleen, lung, heart (cardiac muscle), and skeletal muscle ( $\mathrm{M}$. quadriceps) of fetuses. Enzyme activities in liver, spleen, lung, and cardiac muscle increased rapidly with gestational age, and in skeletal muscle and kidney less rapidly. In brain, on the other hand, the activity remained nearly constant between the 7 th and 24 th week of gestational age. The mean specific activity of transferase in livers from 20-28-week-old fetuses was 20.7 units; in kidney, 3.9 units; in lung, 4.0 units; in spleen, 4.2 units; in cardiac muscle, 4.4 units; in skeletal muscle, 2.6 units; and in brain, 1.2 units. In the case of a stillborn who was born at the 40 th week, transferase specific activities were 20.0 units in liver, 3.0 units in kidney, 2.1 units in lung, 4.5 units in spleen, 1.8 units in cardiac muscle, and 1.5 units in skeletal muscle. A liver from a 5 -month-old baby contained 14.5 units and liver biopsy samples from two 4.5-year-old children had 12.0 and 18.0 units of enzyme activity, respectively. Transferase activity in some tissues from female fetuses seems to be somewhat lower than from the male counterparts (Fig. $3 a, b, c, e$, and $g$ ).

Developmental changes in specific activity of galactokinase in fetal liver, kidney, lung, spleen, cardiac muscle, skeletal muscle, and brain during the 7 th to the 28 th week of pregnancy are illustrated in Figure $4, a-f$. The enzyme activity in liver increased with gestational age. Changes occurring in enzyme activities of other organs showed a more or less similar pattern to that of liver, except brain, of which the activity remained at a constant level of approximately 0.5 units $/ \mathrm{mg}$ protein during this period (Fig. $4 f$ ). The mean specific activity of galactokinase in livers from $27-28$-week-old fetuses was 7.8 units. In other organs from 20-28-week-old fetuses the specific activity was 1.6 units in kidney, 1.9 units in lung, 1.7 units in spleen, 1.6 units in cardiac muscle, 1.3 units in skeletal muscle, and 0.5 units in brain. Galactokinase activity of liver from a stillborn was 6.5 units; from a 5-month-old baby, 7.2; and from two 4.5-year-old children, 5.0 and 6.7 units, respectively.

The specific activity of both enzymes was the highest in liver, indicating that liver is the most important organ for galactose metabolism. According to results shown in Figures 3 and 4 , specific activities of fetal transferase were 2-3 times higher than those of galactokinase in all organs. Levels of liver enzymes from 

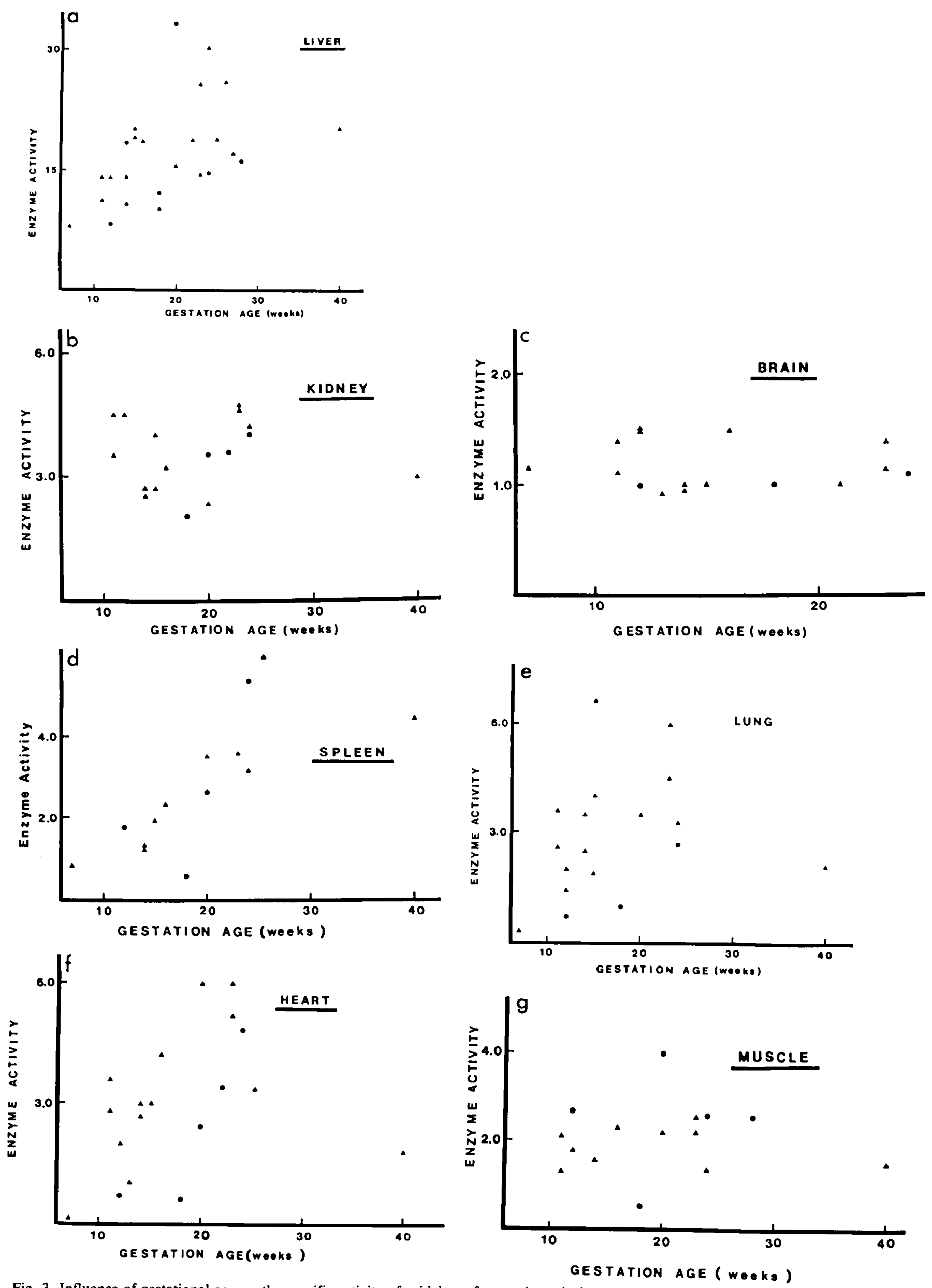

Fig. 3. Influence of gestational age on the specific activity of uridyltransferase. $\Delta$ : male fetuses; $\bullet$ : female fetuses. 

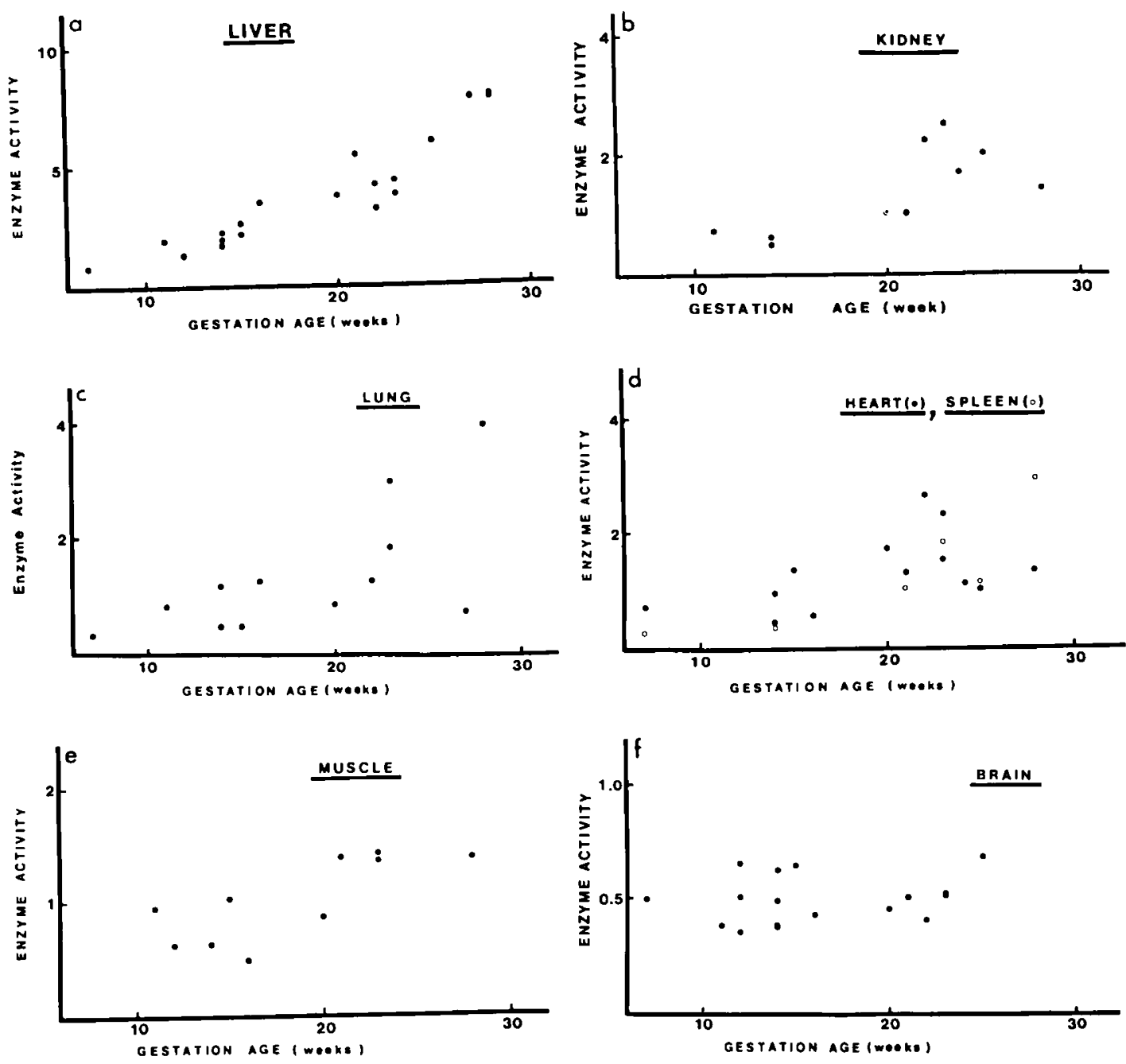

Fig. 4. Influence of gestational age on the specific activity of galactokinase.

children were slightly lower than those from 20-28-week-old fetuses. The transferase activity was negligible in liver from a Caucasian homozygote for classic galactosemia (4 year old) under the condition of routine test. But as the galactose-1phosphate concentration in the test medium increases, a considerable amount of transferase activity was found in the patient; i.e., with $5 \mathrm{mM}$ galactose-1-phosphate in the test medium, as much as 2.6 units of liver transferase activity was obtained.

The specific activity of erythrocytic transferase was 5-6 times higher than that of erythrocytic galactokinase in fetuses, and 15 times higher than that in adults (Table 2). The level of galactokinase activity decreases rapidly with age, whereas that of transferase activity does so only slightly (Table 2 ).

\section{DISCUSSION}

Even though it is rather difficult to generalize the changes occurring in fetal enzymes during pregnancy because of the number of variables which have to be considered, the conclusion can be drawn from our results that the specific activity of the two enzymes studied increased with gestational age. The development of fetal galactokinase and transferase in most organs is very rapid with an increase of $3-10$ fold in the specific activities during the first 5-month period. The enzymatic changes occurring in liver, kidney, lung, spleen, cardiac muscle, and skeletal muscle during this period are comparable to those seen in fatal rat liver $(4,21)$. The activity of both enzymes in rat liver peaked 5-10 days after birth and decreased markedly afterwards (4, 21); transferase activity in rat intestine and kidney decreased postnatally after remaining at a constant level for a couple of days $(3,21)$, whereas galactokinase activity in rat intestine (3) decreased rapidly immediately after birth. Since we have only one stillborn and no data from fetuses older than 28 weeks, we could not determine what kind of developmental changes are occuring during the later period of pregnancy and the first postnatal year. However, we can speculate that enzyme activities in human liver, kidney, muscle, spleen, and lung increase with gestational age until birth or sometime after birth and then subsequently decrease postnatally, considering that a stillborn and 5month-old baby have slightly lower activity of galactokinase and transferase than a 28-week-old fetus. However, the existence of an overshoot after birth is questionable and requires further studies.

The interesting aspect of enzyme development in the brain is that there are almost no further changes in the specific activities of enzymes involved in galactose metabolism after the 7 th to 10 th gestational week, contrary to other organs. It could be concluded, therefore, that the enzymes in brain are unique in respect to their inducibility and development.

Hemolysate transferase activity in newborn infants was approximately $10 \%$ higher than in adults (Reference 21 , Table 2) when it was assayed by the radioactive method. When it was assayed by the UDP-glucose consumption method, which measures the disappearance of UDP-glucose, newborn infants had slightly lower values of transferase activity than adults (21). Lower values in the latter case may be due to the residual epimerase activity in newborn hemolysate in the absence of exogenous NAD which may reproduce UDP-glucose from the 
Table 2. Transferase and galactokinase activity in erythrocytes ${ }^{1}$

\begin{tabular}{|c|c|c|c|c|c|c|}
\hline \multirow{2}{*}{$\begin{array}{l}\text { Source } \\
\text { of blood }\end{array}$} & \multicolumn{3}{|c|}{ Transferase } & \multicolumn{3}{|c|}{ Galactokinase } \\
\hline & $n$ & Mean $\pm S D$ & Range & $n$ & Mean $\pm S D$ & Range \\
\hline Adult ${ }^{2}$ & 56 & $31.5 \pm 6.1$ & $20.0-44.0$ & 14 & $1.87 \pm 0.55$ & $1.28-2.45$ \\
\hline Fetus & 6 & $43.8 \pm 5.0$ & $38.3-50.9$ & 5 & $7.28 \pm 1.96$ & $4.97-9.48$ \\
\hline Cord & 5 & $36.5 \pm 3.8$ & $32.0-41.0$ & 3 & $5.38 \pm 2.27$ & $3.35-7.84$ \\
\hline Infant ${ }^{3}$ & 14 & $35.9 \pm 6.2$ & $28.5-46.1$ & 12 & $5.37 \pm 1.21$ & $4.14-7.87$ \\
\hline
\end{tabular}

1 Micromoles of product produced per hr per $\mathrm{g} \mathrm{Hb}$.

2 Older than 2 years.

${ }^{3}$ Aged hetween 1 and 53 days.

product, UDP-galactose. On the other hand, galactokinase activity in erythrocytes (References 5,28 , and Table 2), as well as in other tissues (3), decreases sharply postnatally, reaching approximately $20 \%$ of the fetal level at the age of 1 year. The accumulation of galactose-1-phosphate, which is thought to be partially responsible for the toxic effect on liver and perhaps other tissues in galactosemia, may be diminished at later ages because of lower galactokinase activity. This phenomenon, together with the reduced exposure to galactose, may explain the symptomatic improvement in classic galactosemic individuals with age even though they are unable to metabolize intravenously administered galactose (26). Galactose-1-phosphate has been shown to be an inhibitor of various enzymes $(7,13,16,22$, $30)$ and its accumulation might also interfere with some of the steps in general nucleotide and RNA metabolism, and thus directly with protein synthesis (29). The abundance of galactose1-phosphate and the lack of UDP-galactose in the classic galactosemia may explain the severity of its pathology compared to galactokinase deficiency.

The specific activity of transferase in fetal liver is approximately 3 times and in fetal hemolysate approximately 5 times higher than that of galactokinase, but approximately 15 times higher in adult hemolysates (Table 2). The difference in the specific activity during development between transferase and galactokinase may indicate that the regulation of the two enzymes during development is different. However, according to Stifel et al. (31), dietary manipulation by sugar feeding to adult rats affects the two enzymes in the same way. Cuatrecasas and Segal reported that the newborn liver enzyme is considerably more stable at $10^{\circ}$ than the adult enzyme in rat (4). It would be of interest to study possible variations in enzyme stability with age or tissue origin and to find the most suitable conditions for enzyme storage.

Our values for the control liver transferase are slightly higher than those of Tedesco (32) and Segal et al. (25), most probably because of the difference in the methods employed in the respective laboratories. Segal $e t$ al. reported that Negro galactosemic variants have $10 \%$ residual transferase activity whereas the activity was undetectable in Caucasian galactosemic variants (25). We found also negligible activity in a Caucasian galactosemic patient when galactose-1-phosphate concentrations from $0.04-$ $0.6 \mathrm{mM}$ were employed in the test. However, when galactose-1phosphate concentration was increased to $5 \mathrm{mM}$, a considerable amount of transferase activity was found, suggesting that the affinity of transferase to galactose-1-phosphate in this patient is very low. It is possible to postulate that the alteration in enzyme activation, its substrate affinity, or its conformation, rather than the complete absence of the enzyme, may be the cause of this genetic disease, at least in some cases. This is supported by the work of Tedesco and Mellmann (33) in which it was indicated that the nature of this genetic disease is "point" mutation which renders the enzyme protein catalytically inactive. Another explanation for the increased activity at higher galactose-1-phosphate concentration may be that galactose-1-phosphate pyrophosphorylase produces UDP-galactose from galactose-1-phosphate and UTP. However, this postulation is improbable in views of considerably low pyrophosphorylase activity in human liver (less than $0.1 \mathrm{nmol}$ UDP-galactose $/ \mathrm{min} / \mathrm{mg}$ protein) compared to transferase activity (1) and the very low (if any) concentration of UTP and magnesium, absolute requirements for pyrophosphorylase.

Galactokinase in fetal erythrocytes and fetal rat liver has a higher $K_{m}$ for galactose and $V_{m}$ than in adult tissues $(19,26,28)$. Preliminary study in our laboratory shows a similar result; liver galactokinase from a child has a slightly lower $\mathrm{K}_{m}$ value for galactose compared to the values from fetuses. Transferase $K_{m}$ values for galactose-1-phosphate are variable. Furthermore, Tedesco (32) found almost no difference between purified and crude enzyme, whereas Segal et al. (25) reported a 2-3 fold increase in $\mathrm{K}_{\mathrm{m}}$ when it was purified. This variation may be partially due to the different concentrations of other substrates employed by different groups. The similarity of transferase affinity to galactose-1-phosphate between fetal and child livers is in agreement with the result from rat liver (3) and suggests that there may be no difference between the enzymes from the two age groups. The study of enzyme kinetics and the identification of isoenzymes in human tissues from various age groups are now in progress.

\section{CONCLUSION}

Developmental aspects of galactose-1-phosphate uridyltransferase and galactokinase were investigated by measuring the specific activities in liver, kidney, lung, spleen, heart, skeletal muscle, and brain of human fetuses at various gestational ages as well as in livers of children. Activities of these enzymes increased in most tissues with gestational age except in brain in which they remained fairly constant during the first 5-month period of fetal life.

The enzymes in fetal, cord, newborn, and adult erythrocytes were studied also. Fetal erythrocytes contained the highest amount of enzymes; in the case of galactokinase the enzyme level was several fold higher than in adult erythrocytes, and in the case of the transferase, only slightly higher. Characteristics of both enzymes, such as $\mathrm{pH}$ optima and substrate affinity, were investigated in fetal livers as well as possible differences in enzyme characteristics between galactosemic and normal subjects.

\section{REFERENCES AND NOTES}

1. Abraham, H. D., and Howell, R. R.: Human hepatic uridine diphosphate galactose pyrophosphorylase. J. Biol. Chem., 244: 545 (1969)

2. Anderson, E. P., Kalckar, H. M., and Isselbacher, K. J.: Defect in uptake of galactose-1-phosphate into liver nucleotides in congenital galactosemia. Science, 125: 113 (1957).

3. Bertoli, D., and Segal, S.: Developmental aspects and some characteristics of mammalian galactose-1-phosphate uridyltransferase. J. Biol. Chem., 241: 4023 (1966).

4. Cuatrecasas, P., and Segal, S.: Mammalian galactokinase: Developmental and adaptive characteristics in the rat liver. J. Biol. Chem., 240: 2382 (1965).

5. Donnell, G. N., Bergen, W. R., and Ng, W. G.: Galactosemia. Biochem. Med., 1: 29 (1967).

6. Fensom, A. H., Benson, P. F., and Blunt, S.: Prenatal diagnosis of galactosemia. Brit. Med. J., 4: 386 (1974).

7. Ginsberg, V., and Neufeld, E.: Abstract of the American Chemical Society Meeting, New York, September 1957, p. 27C.

8. Gitzelmann, R.: Deficiency of erythrocyte galactokinase in a patient with galactose diabetes. Lancet, ii: 670 (1965).

9. Gitzelmann, R.: Hereditary galactokinase deficiency, a newly recognized 
cause of juvenile cataracts. Pediat. Res., 1: 14 (1967).

10. Hammerson, G. Levy, H. L., Frigoletto, F., and Mandell, R.: Comparison of galactose-1-phosphate uridyltransferase in fetal and adult tissues. Clin. Chim. Acta, 60: 281 (1975).

11. Kabacy, G., Hodgmann, J., Donnell, G. N., and Spears, R. L.: Galactose-1phosphate uridyl transferase levels in the newborn. Pediatrics, 38: 125 (1966).

12. Kalckar, H. M., Anderson, E. P., and Isselbacher, K. J.: Galactosemia, a congenital defect in a nucleotide transferase. Biochem. Biophys. Acta, 20: 262 (1956)

13. Kalckar, H. M., and Maxwell, E. S.: Bisynthesis and metabolic function of uridine diphosphoglucose in mammalian organisms and its relevance to certain inborn errors. Physiol. Rev., 38: 77 (1958).

14. Kirkmann, H. N., and Maxwell, E. S.: Enzymatic estimation of erythrocytic galactose-1-phosphate. J. Lab. Clin. Med., 56: 161 (1960)

15. Koo, C., Rogers, S., and Segal, S.: Developmental aspects of galactose-1phosphate uridyltransferase in rat intestine. Biol. Neonate, 27: 153 (1975).

16. Lermann, S.: Carbohydrate metabolism in the experimental galactose cataract. Nature, 184: 1406 (1959).

17. Lineweaver, H., and Burk, D.: The determination of enzyme dissociation constants. J. Amer. Chem. Soc., 56: 658 (1934).

18. Lowry, O. H., Rosebrough, N. J., Farr, A. L., and Randall, R. J.: Protein measurement with the Folin phenol reagent. J. Biol. Chem., 193: 265 (1951).

19. Mathai, C. K., and Beutler, E.: Biochemical characteristics of galactokinase from adult and fetal human red cells. Enzymologia, 33: 223 (1967).

20. Mellmann, W. J., and Tedesco, T. A.: An improved assay of erythrocyte and leukocyte galactose-1-phosphate uridyltransferase: Stabilization of the enzyme by a thiol protection reagent. J. Lab. Clin. Med., 66: 980 (1965).

21. Ng, W. G., Bergen, W. R., Donnell, G. N., and Spears, R. L.: Galactose-1phosphate uridyl transferase activity in hemolysates of newborn infants. Pediatrics, 39: 295 (1967).

22. Oliver, I. T.: Inhibitor studies on uridine diphosphoglucose pyrophosphorylase. Biochem. Biophys. Acta, 52: 75 (1961).
23. Osang, M., Shin-Buehring, Y. S., Wirtz, L., and Schaub, J.: Prenatal diagnosis of galactosemia. (Manuscript in preparation.)

24. Robinson, A. The assay of galactokinase and galactose-1-phosphate uridyltransferase. J. Exp. Med., 118: 359 (1963).

25. Segal, S., Rogers, S., and Holzapple, P. C.: Liver galactose-1-phosphate uridyl transferase: Activity in normal and galactosemic subjects. J. Clin. Invest., 50: 500 (1971).

26. Segal, S., and Roth, H.: Galactose metabolism by rat liver tissue: Influence of age. Science, 142: 1311 (1963).

27. Shin-Buehring, Y. S., Osang, M., Ziegler, R., and Schaub, J.: A method for galactose-1-phosphate uridyltransferase assay and the separation of its isozymes by DEAE-cellulose column chromatography. Clin. Chim. Acta, 70: 371 (1976).

28. Shin-Buehring, Y, S., Osang, M., Ziegler, R., and Schaub, J.: A simple assay for galactokinase using DEAE-cellulose column chromatography. Clin. Chim. Acta., 74: 1 (1977).

29. Sidbury, J. B.: Investigations and speculations on the pathogenesis of galactosemia. In: D. Y. Y. Hsia: Galactosemia, p. 13 (Charles C Thomas, Springfield, Ill., 1969).

30. Sidbury, J. B., and Gardner, L. I. (Editors): Molecular Genetics and Human Disease, p. 61 (Charles C Thomas, Springfield, Ill., 1960).

31. Stifel, F. B., Herman, R. H., and Rosenzweig, N. S.: Dietary regulation of galactose metabolizing enzymes: Adaptive changes in rat jejunum. Science, 162: 692 (1968)

32. Tedesco, T. A.: Human galactose-1-phosphate uridyltransferase. J. Biol. Chem., 247: 6631 (1972)

33. Tedesco, T. A., and Mellmann, W. T.: Galactosemia: Evidence for a structural gene mutation. Science, 122: 727 (1971).

34. This work was supported by Grant Scha $121 / 7$ of the Deutsche Forschungsgemeinschaft.

35. Requests for reprints should be addressed to: J. Schaub, M.D., Kinderklinik der Universität, Lindwurmstr. 4, D-8000 München 2 (West Germany).

36. Received for publication January 10,1977

37. Accepted for publication February 23, 1977

\title{
Lung Development in the Fetal Primate Macaca nemestrina. I. Growth and Compositional Changes
}

\author{
W. ALAN HODSON,"12) SUSAN PALMER, GERALD A. BLAKELY, JANET H. MURPHY, DAVID E. \\ WOODRUM, AND THOMAS E. MORGAN
}

Departments of Pediatrics and Medicine, the Regional Primate Research Center and the Child Development and Mental Retardation Center, University of Washington, Seattle, Washington, USA

\section{Summary}

This report relates lung growth and composition to body growth in 23 fetal and 2 newborn Macaca nemestrina (pigtail monkey) during the last third of gestation.

There was a linear relationship $(r=0.883)$ between gestational age and crown-rump length over the age range studied, and length increased by $1.18 \mathrm{~mm} / \mathrm{day}$. The average increment in body weight was $5.1 \mathrm{~g} /$ day.

Total lung weight increased in a manner similar to total body weight (wet lung weight $=1.91 \pm 0.44 \%$ of total body weight). Lung weight increased by $109 \mathrm{mg} /$ day until term. A correlation of 0.849 was observed between lung weight and gestational age. There was a linear increase in lung dry mass with increasing gestational age $(9 \mathrm{mg} / \mathrm{day}, r=0.701)$ and with increasing body weight $(1.38 \mathrm{mg} / \mathrm{g}$ body weight, $r=0.691)$. The dry weight of fetal lung accounted for $10.8 \pm 2.9 \%$ of total lung weight throughout the gestational period studied. Dry weight increased to $22-23 \%$ after birth.

There was a decrease in protein and DNA per $g$ wet weight of lung with advancing gestational age. Increases in total protein, DNA, and hemoglobin reflected the increasing size of the lung. Because gestational age is correlated with body size, body weight, and lung weight, total lung protein and total lung DNA should not provide any great advantage over total lung weight as a denominator for quantitative estimates of changing cell constituents with growth. Protein and DNA do not increase with gestational age when plotted per $g$ dry lung. DNA per $g$ dry lung tends to decrease with maturity, suggesting an increase in cell size.

\section{Speculation}

Whereas fetal lung growth is linearly related to body growth over the last third of gestation, both lung and body size show wide variance at any given age. Constituents of lung increase in a manner which varies from general lung or body growth and are 